\title{
The Quality Improvement of Educator Recruitment and Selection System in Madrasah
}

\author{
Muhammad Munawir Pohan ${ }^{1}$, M. Nurzen $S^{\mathbf{2}}$ \\ ${ }^{1,2}$ Faculty of Tarbiyah and Teacher Training IAIN Kerinci \\ ${ }^{1}$ munawirpohan8@gmail.com,2nurzen255@gmail.com
}

\begin{abstract}
This study describes the recruitment and selection of teachers at Private Madrasah Aliyah PTP-VI Berangir, North Labuhanbatu Regency, North Sumatra Province. This research was conducted using a qualitative method with a case study design. Data collection tools using interviews with the head of the foundation, the head of the madrasah, the deputy head of the madrasah in the field of curriculum, and certified teachers, observation, and documentation. The research procedures include theme selection, literature reading, formulation of research focus and problems, data collection, data improvement, data processing, data analysis, theoretical dialogue, triangulation of findings, and conclusions of research results. Data analysis techniques include data collection, reduction, presentation, and conclusion. The results of this study are: (1) announcements of teacher recruitment and selection are rarely read or seen by the general public or even though they have used social media Facebook; (2) the admissions experience a few obstacles, namely the many qualifications that are not following the requirements of the madrasah (3) the implementation of all tests involves the principal, madrasah principal, deputy head of the madrasah in the field of curriculum, and teachers who already have professional educator certificates; (4) the results of the selection are carried out by contacting directly the prospective teacher who has passed all the tests and who has the highest score.
\end{abstract}

Keywords: Quality, Recruitment, Selection, Teacher

\begin{abstract}
Abstrak
Penelitian ini bertujuan untuk mendeskripsikan rekrutmen dan seleksi guru di Madrasah Aliyah Swasta PTP-VI Berangir Kabupaten Labuhanbatu Utara Provinsi Sumatera Utara. Penelitian ini dilakukan dengan menggunakan metode kualitatif dengan rancangan studi kasus. Pengumpulan data dilakukan dengan melakukan wawancara dengan kepala yayasan, kepala madrasah, wakil kepala madrasah bidang kurikulum, dan guru yang sudah sertifikasi, observasi, dan dokumentasi. Prosedur penelitian meliputi: pemilihan tema, pembacaan literatur, perumusan fokus dan masalah penelitian, pengumpulan data, penyempurnaan data, pengolahan data, analisis data, dialog teoretik, triangulasi temuan, dan simpulan hasil penelitian Teknik analisis data yang digunakan antara lain: pengumpulan data, reduksi data, penyajian data, dan penarikan kesimpulan. Hasil penelitian ini yaitu: (1) pengumuman rekrutmen dan seleksi guru jarang dibaca atau dilihat masyarakat umum atau pelamar meskipun sudah menggunakan media
\end{abstract}


sosial facebook; (2) penerimaan berkas sedikit mengalami kendala yaitu kualifikasi pelamar banyak yang tidak sesuai dengan yang disyaratkan pihak madrasah (3) pelaksanaan seluruh tes melibatkan kepala yayasan, kepala madrasah, wakil kepala madrasah bidang kurikulum, dan guru yang sudah memilki sertifikat pendidik profesional; (4) pengumuman hasil seleksi dilakukan dengan menghubungi langsung calon guru yang lulus seluruh tes dan yang memiliki nilai tertinggi.

Kata Kunci: Mutu, Rekrutmen, Seleksi, Tenaga Pendidik

\section{Introduction}

The recruitment mechanism for teachers should find the main focus in the recruitment process. Because in this session, the authority owner can select prospective teachers who match the criteria and are desirable for the goals and learning objectives to be achieved. Suppose an error occurs in the recruitment and selection sessions for educators. In that case, it can have a severe impact on the continuity of educational activities that result in the achievement of the goals and ideals of an educational institution because a successful school is a school that can print quality students and achievers. ${ }^{1}$

Implementation of recruitment is a significant task, crucial, and requires great responsibility. The quality of human resources that the school wants to use depends on the recruitment and selection procedures carried out. The school's success in achieving the excellent quality of human resources cannot be separated from the school's efforts in conducting good recruitment. Where through this recruitment process can create a group of applicants who meet the requirements to work at the educational institution. ${ }^{2}$

One of the primary keys in creating professional human resources lies in the recruitment, selection, training, and development of prospective workers. Of course, the recruitment carried out must follow the school's needs that the school has determined. So that the recruitment process that is carried out is not just filling employee vacancies or just getting ordinary human resources. However, human resources are professional in their fields to improve the quality and quality of education in schools. ${ }^{3}$

One of the cases that often occurs in several schools in carrying out the recruitment of teachers and education personnel is the problem of planning for the recruitment of teachers and education personnel who are not mature enough, so that disqualification and

\footnotetext{
${ }^{1}$ Ardiansyah K. A. Rahman, "Rekrutmen Tenaga Pendidik dalam Peningkatan Mutu Madrasah Aliyah Negeri Insan Cendekia Jambi," Nadwa 9, no. 1 (April 25, 2015): 23-38, https://doi.org/10.21580/nw.2015.9.1.518.

${ }^{2}$ Hidayat and Asriyantini, "Analisis Pola Rekrutmen Tenaga Pendidik," Jambura Journal of Educational Management, August 13, 2020, 60-70, https://doi.org/10.37411/jjem.v1i2.163.

${ }^{3}$ Lisnandari, "Manajemen Rekrutmen Tenaga Pendidik di Madrasah Aliyah," Jurnal Isema: Islamic Educational Management 3, no. 2 (2018): 193-200, https://doi.org/10.15575/isema.v3i2.5011.
} 
ineffectiveness of school goals often occur because there are many jobs that some people should try to do. Alone. This is due to the lack of skilled personnel in specific fields of work and the incompatibility of personnel placement concerning their duties and functions. ${ }^{4}$

Several previous studies review teacher recruitment, including a survey entitled "Problematics of Selection and Recruitment of Government Teachers in Indonesia." The results of his research show that there must be a comprehensive improvement in the teacher selection and recruitment system, which is crucial by considering: (1) based on needs; (2) the LPTK produces teacher candidates according to the conditions in the field; (3) Prioritizing competence and qualifications. The recruitment of PPPK teachers, as discussed by the Ministry of Education and Culture, is the first step in improving the quality of teacher input. Fear of tests can hinder selecting qualified teachers, so improvements and adjustments to measurement methods must be made. ${ }^{5}$

Furthermore, the research entitled "Implementation of teacher recruitment in SD Ta'mirul Islam Surakarta studies human resource management in SD Islam." The research results show that the recruitment of new teachers is not held every year because following the school's needs, if there is a vacant position, new teacher recruitment is held to fill the work following the field. Before carrying out activities, it is necessary to prepare for the recruitment of new teachers. The preparation of new teachers must be maximized to obtain reliable teachers to improve the quality of school-based education management. ${ }^{6}$ In addition, the research entitled "Recruitment of educators in high school." The results of his study indicate that the implementation of the recruitment of educators aims to obtain professional educators and have suitable qualifications. Maximum preparation and process are required before carrying out the recruitment. The preparation and recruitment of these educators must be maximized to obtain professional educators with this recruitment. ${ }^{7}$

There are some obstacles to teacher recruitment and selection at PTP-VI Private Madrasah Aliyah Berangir. First, the dissemination of information is less effective, only

\footnotetext{
${ }^{4}$ Arif Supriyadi, "Manajemen Rekrutmen Guru Pendidikan Agama Islam di Sekolah Menengah Atas Islam Terpadu Nur Hidayah Surakarta Kecamatan Kartasura Kabupaten Sukoharjo," Jurnal Hadratul Madaniyah 4, no. 2 (December 22, 2017): 28-32, https://doi.org/10.33084/jhm.v4i2.483.

${ }^{5}$ Elga Andina and Fieka Nurul Arifa, "Problematika Seleksi dan Rekrutmen Guru Pemerintah di Indonesia," Aspirasi: Jurnal Masalah-masalah Sosial 12, no. 1 (June 26, 2021): 85-105, https://doi.org/10.46807/aspirasi.v12i1.2101.

6 Rohmatun Lukluk Isnaini, "Implementasi Rekrutmen Guru di SD Ta'mirul Islam Surakarta (Kajian Manajemen Sumber Daya Manusia di SD Islam)," Jurnal Pendidikan Agama Islam 12, no. 1 (June 2, 2015): 109-20, https://doi.org/10.14421/jpai.2015.121-08.

${ }^{7}$ Qurratu A'yun, Ali Imron, and Imron Arifin, "Rekrutmen Tenaga Pendidik di SMA," Jurnal Pendidikan: Teori, Penelitian, dan Pengembangan 4, no. 7 (July 1, 2019): 850-56, https://doi.org/10.17977/jptpp.v4i7.12613.
} 
relying on social media, Facebook. Second, the applicant's qualifications do not meet the required criteria. ${ }^{8}$ Departing from several previous studies and some of the obstacles above, the authors are interested in researching teacher recruitment and selection in improving the quality of madrasah. The purpose of this study is to describe the recruitment and selection of teachers in madrasah, which consists of recruitment and selection announcements, receipt of files, implementation of all tests, the information of recruitment and election results, and obstacles that occur in recruitment and selection, this study is different from previous research which only focused on teacher recruitment without any improvement in the quality of schools or madrasah.

\section{Methods}

This type of research uses qualitative methods with a case study design. Qualitative research with a case study design is one type of qualitative research. The researcher conducts an in-depth exploration of the program of events, processes, activities of one or more people. The source of this research data is interviews with the foundation president, the head of the madrasah, the vice-principal for curriculum, and certified teachers. The data collection instrument was through several techniques, namely observation, interviews, and document analysis. The research procedure includes theme selection, literature reading, formulation of research focus and problems, data collection, data refinement, data processing, data analysis, theoretical dialogue, triangulation of findings, and conclusions of research resultstechniques of data analysis through three stages, namely data reduction, data presentation, and conclusion. ${ }^{9}$

\section{Discussion}

\section{Teacher Recruitment and Selection System at MAS PTP-VI Berangir}

The stages in the teacher recruitment and selection process at Madrasah Aliyah PTPVI Berangir include: (a) recruitment and selection announcements; (b) receipt of files; (c) implementation of the selection; and (d) announcement of election results. ${ }^{10}$

The first stage, the announcement of recruitment and selection, is done by spreading recruitment and selection information on social media Facebook using the madrasah account

\footnotetext{
${ }^{8}$ Ismail Pohan, Interview with Kepala Madrasah Aliyah Swasta PTP-VI Berangir, May 14, 2021.

${ }^{9}$ Rasmuin and Saidatul Ilmi, "Strategi Implementasi Pendidikan Karakter di Masa Pandemi Covid-19; Studi Kasus di MAN 2 Banyuwangi," Indonesian Journal of Islamic Education Studies (IJIES) 4, no. 1 (June 29, 2021): 17-36, https://doi.org/10.33367/ijies.v4i1.1629.

10 Pohan, Interview with Kepala Madrasah Aliyah Swasta PTP-VI Berangir.
} 
name. Announcements on Facebook social media contain information about the type of formation needed, age limit, minimum length of service, types of documents required, and addresses for sending all recruitment and selection requirements files. There are a few obstacles and obstacles in this first stage, namely the dissemination of recruitment information that is still less effective and only uses social media, Facebook, so it is rarely read or seen by the general public and applicants. Madrasah can accomplish anticipation in expanding the dissemination of recruitment and selection information by sending chain messages to all madrasah teachers to be conveyed to all families, neighbours, and the community where each teacher lives. In addition, distribute posters or brochures in strategic places. ${ }^{11}$ In the second stage, the applicant's acceptance of the required documents is submitted to the madrasah. Applicants interested in serving at PTP-VI Berangir Private Madrasah Aliyah can entrust or deliver their files directly to the madrasah. Usually, it is assigned to the school security or the picket teacher on duty and later handed over to the head of the madrasah. For this stage, there is no limit on the number of applicant files received. ${ }^{12}$

In the third stage, various types of tests are carried out. The first type of test is file selection (passport photos, photocopies of ID cards, application letters, biodata, legalization of undergraduate diplomas, and transcripts of grades). At this stage, the emphasis is placed on several primary documents, namely photocopies of ID cards, legalization of certificates, and transcripts of grades. For photocopies of ID cards, the concern is the distance between the applicant's address and the madrasah. Because the priority is the applicant's address who is still close to the madrasah, then, for a diploma, it is essential to note that the applicant's significance must be following the required formation. This is indeed very necessary because the suitability of the applicant's major with the appearance needed by the madrasah can help the educator's career in the long term, namely being proposed to be a prospective professional educator. In addition, it is also beneficial for madrasahs to prepare for accreditation in the next period.

Furthermore, what needs to be considered on the grade transcript is the value of the course according to the applicant's formation, whether the score is good or sufficient. This is very important because it is hoped that the knowledge taught to students will be good with the applicant's majors following the required shape. There are a few obstacles in accepting

\footnotetext{
${ }^{11}$ Ratna Juwita, Interview with Wakil Kepala Madrasah Bidang Kurikulum MAS PTP-VI Berangir, May 17, 2021.

${ }^{12}$ Pohan, Interview with Kepala Madrasah Aliyah Swasta PTP-VI Berangir.
} 
applicants' files or prospective teachers. Namely, many applicants do not match the qualifications requested and needed for the madrasah. Of course, the madrasah must be more careful and selective in checking all applicant files that the madrasah has received. In addition, the madrasah adds time or extends the time for registration and receipt of files so that applicants who can meet the requirements and qualifications are found. ${ }^{13}$

The next test is an interview. Applicants or prospective teachers are interviewed directly by the head of the madrasah. The list of interview questions includes the ability to read the Qur'an, the ability to operate a laptop/computer, the applicant's motivation to serve in the madrasah, the applicant's work experience, the applicant's willingness to help at the madrasah for a minimum of two years, notification of the salary amount if the applicant is later declared to have passed the test and accepted to teach at the madrasah, information of teacher duties and responsibilities in madrasah, notification of teacher discipline and the applicable penalties if a teacher violates one of the rules in Madrasah, willingness to work full time for applicants, information of uniforms used by applicants after passed, questions related to religious knowledge, and questions related to the applicant's a science/department. ${ }^{14}$

In the practice test, applicants receive notification before taking the teaching test, including preparing a lesson plan and syllabus for one meeting with a free theme. Applicants are asked to prepare a handout of at least five slides in the form of a PowerPoint file. Applicants are requested to use learning media in the form of laptops and projectors. This test aims to see the readiness of prospective educators in carrying out learning activities in the classroom and improve motivation and quality of learning in the school. In addition, the purpose of the teaching practice test is to facilitate applicants/prospective teachers in learning, practising, discussing matters related to teaching skills in teaching in the classroom. All teachers attended the teaching practice test to see the mentality and readiness of prospective teachers in carrying out the learning process in the school. Usually, the concern is how the future teacher opens the lesson, how the prospective teacher carries out the core learning activities, and how the prospective teacher closes the study. ${ }^{15}$

The fourth stage is to announce the results of the selection. All tests that applicants have passed will be reported with the results and scores. The deputy's head makes the announcement of the election results of the madrasah in the field of the curriculum by

\footnotetext{
${ }^{13}$ Pohan. Interview with Kepala Madrasah Aliyah Swasta PTP-VI Berangir.

${ }^{14}$ Hidayati, Interview with Guru Sertifikasi MAS PTP-VI Berangir, May 18, 2021.

15 Juwita, Interview with Wakil Kepala Madrasah Bidang Kurikulum MAS PTP-VI Berangir.
} 
contacting directly via cellphone or WhatsApp, the prospective teacher who gets the highest score from the entire test that has been passed by all applicants/prospective teachers. Future teachers who are not called or contacted by the deputy head of the madrasah for curriculum are disqualified. ${ }^{16}$

\section{Recruitment and Selection}

In the Law of the Republic of Indonesia Number. 14 of 2005 concerning teachers and lecturers in article 24 paragraph 1 states that the government must meet the needs of teachers, both in number, academic qualifications, or in the overall competition, to ensure the continuity of the unity of early childhood learning through the official learning path and to ensure the continuity of primary and secondary learning. The government organizes them. ${ }^{17}$ The ongoing process shows that there is no government commitment to an efficient teacher recruitment system, overlapping authorities, the influence of the interests of various parties, and the growing stigma that status as a civil servant is more meaningful than quality. Recruitment of teachers is constantly exploring the pattern of universal CPNS acceptance, which is not specified following the nature of the work of educators. ${ }^{18}$

The process of recruiting educators in educational institutions in schools is an effort to find teachers who have competence, skills, and experts in educating and teaching according to their fields. No less important is the behaviour possessed by a teacher, namely being honest and having a healthy body to carry out his duties in educating the nation's children. The mechanism for the recruitment of educators should find immediate attention in terms of the recruitment process. Because in this session, the authority owner can sort and select prospective teachers according to the desired criteria for the ideals and educational goals to be achieved. ${ }^{19}$ Recruitment of educators and education is a set of activities and processes used to obtain qualified people at a place and time following applicable legal requirements. People and schools can select each other based on their respective best interests in the long and short term. ${ }^{20}$

\footnotetext{
${ }^{16}$ M Hayat, Interview with Guru Sertifikasi MAS PTP-VI Berangir, May 15, 2021.

${ }^{17}$ Nani I. Rajaloa and Rustam Hasyim, "Manajemen Perencanaan dan Rekrutmen Tenaga Pendidik oleh Dinas Pendidikan Kota Ternate,” Edukasi 16, no. 1 (March 7, 2018), https://doi.org/10.33387/j.edu.v16i1.617.

Andina and Arifa, "Problematika Seleksi dan Rekrutmen Guru Pemerintah di Indonesia."

19 Rony, "Sistem Rekrutmen Tenaga Pendidik (Guru)," Miyah : Jurnal Studi Islam 14, no. 2 (May 11, 2019): 37-57, http://dx.doi.org/10.33754/miyah.v14i2.147.g117.

20 Pasiska Pasiska, Mutyati Mutyati, and Rabial Kanada, "Pelaksanaan Rekrutmen Tenaga Pendidik dan Kependidikan di Sekolah Dasar Islam Terpadu Lan Tabur Kota Pagar Alam," El-Idare: Jurnal Manajemen Pendidikan Islam 6, no. 2 (2020): 85-96, https://doi.org/10.19109/elidare.v6i2.6465.
} 
Recruitment management is a process that links management functions to achieve efficient and effective recruitment. Recruitment management is a series of planned activities to obtain the expected human resources. In principle, employee recruitment is the process of finding, creating, and attracting applicants to become employees by certain institutions. Next, recruitment is also defined as a series of activities to find and attract job applicants with the necessary motivation, skills, and knowledge to cover the deficiencies identified in educator planning. ${ }^{21}$

To obtain prospective teachers or educators who are professional, must meet the qualifications, and promise to occupy certain positions is not easy. Several principles must be adhered to in the planning or implementation of teacher recruitment, including: (1) teacher recruitment must be carefully designed and planned to meet the need to obtain professional teachers; (2) recruitment of new teachers must be carried out objectively. This means that the selection committee for new teacher employees determines applicants who pass and applicants who do not pass objectively; (3) to get a professional candidate, the material for the selection of new teacher employees should comprehensively cover all aspects of the requirements that prospective teachers must possess. ${ }^{22}$

Principals play an active role in bringing changes to educational institutions by influencing all learning components such as teachers, students, and residents. The principal has the responsibility and authority to recruit and select appropriate teachers. Following the wishes of the school he leads, errors in selecting educators will significantly impact the educational process in the future. The application of immature teacher recruitment often leads to the formation of discrepancies with the expectations and desires of the school. ${ }^{23}$

The principal must take action when he sees a vacancy in the school by implementing a plan to make data on the recruitment of new educators who want to fill the vacancy according to the criteria for vacant positions in the school. To ensure effectiveness and efficiency, the withdrawal of the number of compulsory educators following the needs of no more and no less and the quality of the required teaching staff must carry out tasks, both main, functional, and administrative tasks in schools. Principals involve the role of vice-

\footnotetext{
${ }^{21}$ Maivia Sandela, "Manajemen Rekrutmen Tenaga Pendidik di SDIT Sa'adiah Kecamatan Kubung Kabupaten Solok," al-fikrah: Jurnal Manajemen Pendidikan 7, no. 2 (October 22, 2019): 155-66, https://doi.org/10.31958/jaf.v7i2.1674.

22 Lisnandari, "Manajemen Rekrutmen Tenaga Pendidik di Madrasah Aliyah."

23 Erialdy, Ade Indra Permana, and Tb Yudi Muhtadi, "Pendampingan Kepala Sekolah pada Kegiatan Rekrutmen Guru sebagai Syarat Pendirian Sekolah Menengah Pertama (SMP) Citra Insan Mulia," Jurpikat (Jurnal Pengabdian Kepada Masyarakat) 2, no. 1 (April 20, 2021): 117-25, https://doi.org/10.37339/jurpikat.v2i1.491.
} 
principals, heads of administration, and school foundations in formulating plans for recruiting educators, which are carried out at the beginning of each year or new school year where schools need educators. The planning process that the school tries also looks at various types of aspects such as the number of educators required, commitment to schools, and the quality of educators who must be a scholar. ${ }^{24}$

\section{Educators (Teachers)}

Educators are a group of human resources assigned to guide, teach and train students. They are teaching staff, educators who are promoted explicitly from the main task of teaching at the elementary and secondary learning levels. Educators are a force, a resource that can move things. So, educators can be called human resources (HR) or those responsible for teaching and learning activities in determining the quality. ${ }^{25}$

Educators are responsible for developing their students covering physical and spiritual aspects (cognitive, affective, and psychomotor), leading them to a better direction and drawing closer to God Almighty. An educator is a teacher in a school who can come from a formal learning background with at least a bachelor's status and already has legal provisions as a teacher based on the applicable teacher law. ${ }^{26}$

Educators should be the architects of education in their classes. Educators also produce quality educational processes but always prioritize fun learning for students. Therefore, educators must design instruction according to the needs of the students being taught and carry out education according to the teacher's plans. ${ }^{27}$ Educators or teachers are professionals who can make their students design, analyze, and formulate the problems they face. $^{28}$

Being an educator means sharing knowledge and good education with students. Students certainly want their learning experience to be unforgettable and be a memory for the rest of their lives, and it can lead them to achieve big dreams in the future. ${ }^{29}$ Educators

\footnotetext{
${ }^{24}$ Hidayat and Asriyantini, "Analisis Pola Rekrutmen Tenaga Pendidik."

${ }^{25}$ Sandela, "Manajemen Rekrutmen Tenaga Pendidik di SDIT Sa'adiah Kecamatan Kubung Kabupaten Solok."

${ }^{26}$ Rony Rony, "Sistem Rekrutmen Tenaga Pendidik (Guru)," Miyah: Jurnal Studi Islam 14, no. 2 (May 11, 2019): 37-57, http://dx.doi.org/10.33754/miyah.v14i2.147.g117.

${ }^{27}$ Leonard, "Kompetensi Tenaga Pendidik di Indonesia: Analisis Dampak Rendahnya Kualitas SDM Guru dan Solusi Perbaikannya," Formatif: Jurnal Ilmiah Pendidikan MIPA 5, no. 3 (February 25, 2016), https://doi.org/10.30998/formatif.v5i3.643.

${ }^{28}$ Barkat Amiruddin, "Persepsi Tenaga Pendidik dan Tenaga Kependidikan Terhadap Program Belajar dari Rumah | Jurnal As-Salam," Jurnal As-Salam 4, no. 1 (June 14, 2020): 28-36, https://doi.org/10.37249/assalam.v4il.146.

${ }^{29}$ Leonard, "Kompetensi Tenaga Pendidik di Indonesia."
} 
deliberately influence other people (students) to reach a greater level of perfection (humanity). The status of educators in this model can be carried out by anyone, anywhere, and anytime. ${ }^{30}$

The vital position of educators in encouraging student education is to increase students' willingness or motivation to learn. As educators, teachers should do the following:

1. Provide various examples and representations of subject matter to students.

2. Encourage a high degree of interaction in teaching.

3. Link lesson modules to the real world. ${ }^{31}$

\section{Improving School/Madrasah Quality}

Quality is considered a significant part because quality shows the advantages of a product compared to other products. Quality improvement is the effort of each institution to produce goods and service products. Likewise in education is a significant part to be observed. Quality is an integral part of all schedules in an organization, and improving quality is probably the most crucial task experienced by any institution. However, despite the significance, there are many other comments about the concept of good quality. ${ }^{32}$

The process of improving the quality of education is undoubtedly through the strategic steps of school management to improve the quality of schools. Management strategy is an effort to meet educational needs in improving students quality. Quality is a form of service to meet the needs and expectations of students where the quality is directly oriented to science and technology. That is, integrated quality management in education is a continuous improvement to correct and meet the expected needs of students in educational service delivery. Efforts to improve the quality of education include curriculum components, educational infrastructure, teaching staff, and education in Indonesia, are still categorized as low and have not seen significant results. The implementation of quality education programs is tried to improve the education component in schools. Education builds the quality of students in the face of the turmoil of the times. The quality is assessed from the level of satisfaction of citizens as consumers of the educational institution's services. ${ }^{33}$

\footnotetext{
30 Sandela, "Manajemen Rekrutmen Tenaga Pendidik di SDIT Sa'adiah Kecamatan Kubung Kabupaten Solok."

${ }^{31}$ K. A. Rahman, "Rekrutmen Tenaga Pendidik dalam Peningkatan Mutu Madrasah Aliyah Negeri Insan Cendekia Jambi."

32 Muhammad Fadhli, "Manajemen Peningkatan Mutu Pendidikan," Tadbir: Jurnal Studi Manajemen Pendidikan 1, no. 2 (December 18, 2017): 215-40, https://doi.org/10.29240/jsmp.v1i2.295.

33 Rachmat Satria et al., "Peningkatan Mutu Sekolah melalui Manajemen Hubungan Masyarakat," Jurnal Akuntabilitas Manajemen Pendidikan 7, no. 2 (September 29, 2019): 199-207, https://doi.org/10.21831/amp.v7i2.26018.
} 
Interpretation of quality in education refers to the learning process and learning outcomes. A quality learning process can be seen from various inputs. On the other hand, learning outcomes refer to the achievements achieved by the school in each specific period. Operations and quality learning outcomes are interrelated, but a good process is not misguided. Schools are required to formulate well the targets to be achieved within the specified period. ${ }^{34}$

One of the substantial efforts to improve the quality of education is by strengthening citizen participation, accommodating thoughts, aspirations and exploring the capabilities of citizens to ensure democratization, transparency, and accountability. Citizen participation is considered meaningful because it is one of the realizations of the essence of a just democracy, so an institution is formed as a forum for citizens to improve the quality of schools called school committees. This means that the community has the right to obtain a quality education. There is also an obligation to participate and provide it, both in providing funds for the procurement, development, and maintenance of learning facilities and infrastructure as well as the expertise or capabilities needed in program management and implementation. ${ }^{35}$ Quality education is the hope and demand of all education stakeholders. Everyone would prefer to study at institutions that have good quality. On this basis, schools/educational institutions must provide good quality and service not to be left behind and compete with other educational institutions. ${ }^{36}$

\section{Conclusion}

The Foundation's teacher recruitment and selection process, and the head of the PTPVI Berangir Private Madrasah Aliyah, have gone through the correct procedure stage. Although several obstacles and obstacles were experienced, the madrasah was able to quickly overcome and create various alternatives so that the recruitment and selection process could continue. Recruitment announcements are made openly. All tests are carried out rigorously and thoroughly involving competent elements in their fields so that the quality of madrasahs can improve and even improve in the future. Prospective teachers who have been forged from the start are expected to carry out the teaching and learning process well

\footnotetext{
34 Handriyani Timor, "Mutu Sekolah; antara Kepemimpinan Kepala Sekolah dan Kinerja Guru," Jurnal Administrasi Pendidikan 25, no. 1 (June 5, 2018): 21-30, https://doi.org/10.17509/jap.v25i1.11568.

35 Mia Noprika, Ngadri Yusro, and Sagiman Sagiman, "Strategi Kepala Sekolah dalam Peningkatan Mutu Pendidikan," Andragogi: Jurnal Pendidikan Islam dan Manajemen Pendidikan Islam 2, no. 2 (August 10, 2020): 224-43, https://doi.org/10.36671/andragogi.v2i2.99.

${ }^{36}$ Fadhli, "Manajemen Peningkatan Mutu Pendidikan."
} 
in the classroom. So that students in the class can receive fun learning, and students are expected to absorb the knowledge transferred by educators quickly. Even during the current covid-19 pandemic, learning uses technology to support distance learning. No more difficult for teachers to use technology. More than $70 \%$ of all affairs in madrasahs use computers and the internet, starting from registration, assessment of student learning outcomes, national exams, and madrasah final exams, teacher administration, accreditation, and management of users as reports of school operational assistance funds.

This research is expected to be valuable and helpful for educational institutions, especially madrasahs, in recruiting and selecting new teachers transparently and openly to the general public. This research still has many shortcomings and is far from perfect. This research still has many shortcomings and is far from perfect. In the future, further research can complement the results that have not been achieved in the research findings.

\section{References}

Amiruddin, Barkat. "Persepsi Tenaga Pendidik dan Tenaga Kependidikan terhadap Program Belajar dari Rumah | Jurnal As-Salam.” Jurnal As-Salam 4, no. 1 (June 14, 2020): 28-36. https://doi.org/10.37249/as-salam.v4i1.146.

Andina, Elga, and Fieka Nurul Arifa. "Problematika Seleksi dan Rekrutmen Guru Pemerintah di Indonesia." Aspirasi: Jurnal Masalah-masalah Sosial 12, no. 1 (June 26, 2021): 85-105. https://doi.org/10.46807/aspirasi.v12i1.2101.

A'yun, Qurratu, Ali Imron, and Imron Arifin. "Rekrutmen Tenaga Pendidik di SMA.” Jurnal Pendidikan: Teori, Penelitian, dan Pengembangan 4, no. 7 (July 1, 2019): 850-56. https://doi.org/10.17977/jptpp.v4i7.12613.

Erialdy, Ade Indra Permana, and Tb Yudi Muhtadi. "Pendampingan Kepala Sekolah pada Kegiatan Rekrutmen Guru Sebagai Syarat Pendirian Sekolah Menengah Pertama (SMP) Citra Insan Mulia.” Jurpikat (Jurnal Pengabdian Kepada Masyarakat) 2, no. 1 (April 20, 2021): 117-25. https://doi.org/10.37339/jurpikat.v2i1.491.

Fadhli, Muhammad. "Manajemen Peningkatan Mutu Pendidikan." Tadbir: Jurnal Studi Manajemen Pendidikan 1, no. 2 (December 18, 2017): 215-40. https://doi.org/10.29240/jsmp.v1i2.295.

Hayat, M. Interview with Guru Sertifikasi MAS PTP-VI Berangir, May 15, 2021.

Hidayat, and Asriyantini. “Analisis Pola Rekrutmen Tenaga Pendidik.” Jambura Journal of Educational Management, August 13, 2020, 60-70. https://doi.org/10.37411/jjem.v1i2.163.

Hidayati. Interview with Guru Sertifikasi MAS PTP-VI Berangir, May 18, 2021.

Isnaini, Rohmatun Lukluk. "Implementasi Rekrutmen Guru di SD Ta'mirul Islam Surakarta (Kajian Manajemen Sumber Daya Manusia di SD Islam)." Jurnal Pendidikan Agama Islam 12, no. 1 (June 2, 2015): 109-20. https://doi.org/10.14421/jpai.2015.121-08. 
Juwita, Ratna. Interview with Wakil Kepala Madrasah Bidang Kurikulum MAS PTP-VI Berangir, May 17, 2021.

K. A. Rahman, Ardiansyah. "Rekrutmen Tenaga Pendidik dalam Peningkatan Mutu Madrasah Aliyah Negeri Insan Cendekia Jambi." Nadwa 9, no. 1 (April 25, 2015): 23-38. https://doi.org/10.21580/nw.2015.9.1.518.

Leonard. "Kompetensi Tenaga Pendidik di Indonesia: Analisis Dampak Rendahnya Kualitas SDM Guru dan Solusi Perbaikannya." Formatif: Jurnal Ilmiah Pendidikan MIPA 5, no. 3 (February 25, 2016). https://doi.org/10.30998/formatif.v5i3.643.

Lisnandari. "Manajemen Rekrutmen Tenaga Pendidik di Madrasah Aliyah.” Jurnal Isema: Islamic Educational Management 3, no. 2 (2018): 193-200. https://doi.org/10.15575/isema.v3i2.5011.

Noprika, Mia, Ngadri Yusro, and Sagiman Sagiman. "Strategi Kepala Sekolah dalam Peningkatan Mutu Pendidikan." Andragogi: Jurnal Pendidikan Islam Dan Manajemen Pendidikan Islam 2, no. 2 (August 10, 2020): 224-43. https://doi.org/10.36671/andragogi.v2i2.99.

Pasiska, Pasiska, Mutyati Mutyati, and Rabial Kanada. "Pelaksanaan Rekrutmen Tenaga Pendidik dan Kependidikan di Sekolah Dasar Islam Terpadu Lan Tabur Kota Pagar Alam." El-Idare: Jurnal Manajemen Pendidikan Islam 6, no. 2 (2020): 85-96. https://doi.org/10.19109/elidare.v6i2.6465.

Pohan, Ismail. Interview with Kepala Madrasah Aliyah Swasta PTP-VI Berangir, May 14, 2021.

Rajaloa, Nani I., and Rustam Hasyim. "Manajemen Perencanaan dan Rekrutmen Tenaga Pendidik oleh Dinas Pendidikan Kota Ternate.” Edukasi 16, no. 1 (March 7, 2018). https://doi.org/10.33387/j.edu.v16i1.617.

Rasmuin, and Saidatul Ilmi. "Strategi Implementasi Pendidikan Karakter di Masa Pandemi Covid-19; Studi Kasus di MAN 2 Banyuwangi." Indonesian Journal of Islamic Education Studies (IJIES) 4, no. 1 (June 29, 2021): 17-36. https://doi.org/10.33367/ijies.v4i1.1629.

Rony, Rony. "Sistem Rekrutmen Tenaga Pendidik (Guru)." Miyah : Jurnal Studi Islam 14, no. 2 (May 11, 2019): 37-57. http://dx.doi.org/10.33754/miyah.v14i2.147.g117.

Sandela, Maivia. "Manajemen Rekrutmen Tenaga Pendidik di SDIT Sa'adiah Kecamatan Kubung Kabupaten Solok." Al-Fikrah: Jurnal Manajemen Pendidikan 7, no. 2 (October 22, 2019): 155-66. https://doi.org/10.31958/jaf.v7i2.1674.

Satria, Rachmat, Achmad Supriyanto, Agus Timan, and Maulana Amirul Adha. "Peningkatan Mutu Sekolah melalui Manajemen Hubungan Masyarakat." Jurnal Akuntabilitas Manajemen Pendidikan 7, no. 2 (September 29, 2019): 199-207. https://doi.org/10.21831/amp.v7i2.26018.

Supriyadi, Arif. "Manajemen Rekrutmen Guru Pendidikan Agama Islam di Sekolah Menengah Atas Islam Terpadu Nur Hidayah Surakarta Kecamatan Kartasura Kabupaten Sukoharjo.” Jurnal Hadratul Madaniyah 4, no. 2 (December 22, 2017): 28-32. https://doi.org/10.33084/jhm.v4i2.483.

Timor, Handriyani. "Mutu Sekolah; Antara Kepemimpinan Kepala Sekolah dan Kinerja Guru." Jurnal Administrasi Pendidikan 25, no. 1 (June 5, 2018): 21-30. https://doi.org/10.17509/jap.v25i1.11568. 